\title{
PROGRESS IN SILVICULTURAL RESEARCH IN THE PULP AND PAPER INDUSTRY OF CANADA ${ }^{1}$
}

\author{
BY A. KOROLEFF
}

Pulp and Paper Research Institute of Canada, Montreal, Quebec.

Evaluation of progress in silvicultural research depends greatly on the point of view. Some years ago Julian Rothery told a story about a barefooted hobo who was given a pair of shoes that were full of holes. $\mathrm{He}$ looked them over and said, "They are not so hot, but they certainly beat nothing all to hell." From such a philosophical angle, our progress in silvicultural research may be highly rated. Some, however, are seriously alarmed at the fact that this progress has not been much greater. Generally speaking, silvicultural research in the pulp and paper industry is still begging for attention, and the funds which it receives are rarely more than crumbs.

Adequate provisions for silvicultural research are contingent on a whole-hearted recognition of the need for silviculture. In 1946, in its "Statement of Forest Policy", our industry made the following declaration on the subject of silviculture:

"As part of the forest management policy, each forest operator should obtain and apply the knowledge necessary to reproduce and grow forests, so that the yield per acre may be increased and the period of rotation shortened. In particular, such cutting techniques should be adapted that will accelerate prompt natural restocking of the forest."

"Government activities and those of industry associations should be extended to provide and disseminate the scientific knowledge necessary for maximum wood production."

It appears that many of the high officials of our industry are still hesitant about making serious investments on behalf of research or practice in silviculture, both with regard to their own companies and to such work as could be done best through the industry's collective effort. The prevalent tendency is to provide principally for such studies as will produce quick returns. However, there would seem to be a growing tendency on the part of company executives to give silvicultural research a high priority.

In this connection I should like to quote from a recent letter written by B. F. Avery:

"It seems to me that each member company realizes the necessity of meeting competition in costs and will, by its own initiative, strive for these improvements in operations that will reduce costs. Furthermore, it is my conviction that our industry will never go out of business through lack of attention to research in the logging aspect of our industry. But, it is very possible that parts of our industry will go out of business, to the great detriment of Canadian economy, through failure to maintain the supply of wood required by the presently installed capacity and the expansions constantly being projected."

1. Paper presented at the fortieth annual meeting of the Canadian Society of Forest Engineers, Fredericton, N.B., October 4 to 7, 1948. 
"No feature of woodlands research is more important to the industry, now and for many years to come, than that of silviculture. It is not enough to accumulate knowledge and write reports to be distributed and filed. It is essential that the knowledge now at hand be tested by demonstration, to the end that the policy of our industry may be implemented throughout the whole of Canada. Until the industry faces the necessity of growing trees to the capacity of the land to produce trees, on the areas on which it holds cutting rights, our policy is of no avail and furthermore may prove to be a most serious delusion."

I am hopeful that full appreciation by our industry of the need and urgency of silviculture will be speeded up by authoritative information now being published on disastrous, world-wide effects of abuse of land. ${ }^{1}$ The land is the only real source of necessities for mankind, but already this source has been alarmingly undermined in many parts of most countries through deterioration and destruction of its protective plant cover and the consequent losses of its topsoil and soil water. The resultant misery is increasing.

I will briefly refer to three major channels that are serving silvicultural research in our industry; the companies' woods departments; the industry's central research agency-the Pulp and Paper Research Institute of Canada; and the pertinent governmental and other organizations, including the forest schools.

Probably no one knows definitely how much silvicultural research has been conducted within the companies, and with what effect, as only a fraction of this data has been published. My impression is that not very much has been done as yet. Leif Holt, a Woodlands Research Associate in our Institute, has just completed under my direction a survey of silvicultural research conducted by the pulp and paper companies in the east, and his report is now being printed. ${ }^{2}$ It throws some additional light upon the picture, but of necessity is far from being exhaustive, as only 17 unpublished reports were provided for this survey. Some of the companies are rather shy about divulging their inside information on this subject, and some stated that they had practically nothing to contribute.

The Pulp and Paper Research Institute of Canada was established (though not under that name) in 1929, but only since 1942 has there been a small volume of woodlands research introduced into its program. For the first 3 or 4 years these studies had to do almost entirely with efficiency of logging. Silvicultural research was started in 1946, when H. D. Long was appointed a Woodlands Research Associate. That work was interrupted a year ago by his resignation and was resumed last spring with the appointment of Leif Holt.

A year ago, when I was appointed Director of Woodlands Research in the Institute on full time, I was requested to outline a plan for an 1. Papers given at the last meeting of the American Association for the Advancement of
Science; "Road to Survival", by William Vogt; "Ape and Essence", by Aldous Huxley.

2. This report by L. Holt, "A Survey of Silvicultural Studies Conducted by the member Pulp and Paper Research Institute, 3420 University St., Montreal (price \$1). 
extension of the woodlands research activities. My proposal was prepared about half a year ago and, of course, refers in part to the needs of silvicultural research. I expect that this proposal will be dealt with by the Institute at the end of this month. Meanwhile I am not in a position to speak of the prospects.

The Dominion Forest Service and most of the other agencies outside of our industry concerned with silvicultural research have of late shown a definite increase in vitality. They have also shown a tendency to cooperate closely with our industry in the solution of its problems. I hope that the extent and intimacy of this working contact will continue to expand.

Probably most of our practising foresters who deal principally with logging, consider silvicultural research only in terms of papers and bulletins by specialists, and do not sufficiently endeavour to find out things for themselves in the course of their almost daily direct contact with the forest. Many silvicultural problems are so complex that their solution calls for full time efforts by the best specialists, and we need more of such men. On the other hand, too sharp a division between research men and the practising forester-operator would be decidedly undesirable. Here, a considerable overlap would be much preferable to a gap.

Nearly every practising forester should do some silvicultural research on his own when he can. I do not mean that he should undertake any elaborate studies requiring special funds and much time, and which could seriously deflect the forester from his immediate obligations. I merely mean that such observations and experiments as can be done quickly and easily in passing should be done. If he is, for instance, concerned about regeneration failure in a certain case he can check, on a small scale, certain theories by the cutting of certain trees, or by scattering a bunch of slash, or by scraping off the duff with his heel to expose the soil, or by other simple means. He then should mark and memorize the spot, make a note in his notebook, and in due course re-examine that spot closely to observe what has actually transpired. European foresters do this ofen; and it is a good practice for us to acquire.

Silvicultural research specialists merely contribute the material needed for the progress in silviculture, but this progress can be actually achieved only by those dealing with our commercial operations on the ground. I will illustrate this point.

In a rural community a little girl, a farmer's daughter, was leading a cow. She met a prim, elderly spinster, who asked where she was taking that cow. The girl replied, "To the bull." The old lady was shocked. "Oh dear, oh dear, and you such a little girl! Could not your father do it?" The girl said, "No, madam! It has to be a bull."

The forester-operator acts, in a way, as a breeding bull. The kind of reproduction and quality of stock depend to a great extent on his qualifications and actions. If he is uninformed or careless he may act, unwittingly, "as a bull in a china shop", except that the damage often is not immediately apparent. 